YEARBOOK
of ANTITRUST
and REGULATORY
STUDIES
www.yars.wz.uw.edu.pl
Peer-reviewed scientific periodical, focusing on legal and economic issues of antitrust and regulation. Creative Commons Attribution-No Derivative Works 3.0 Poland License.

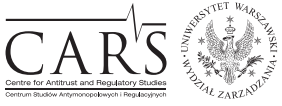

Centre for Antitrust and Regulatory Studies, University of Warsaw, Faculty of Management www.cars.wZ.uw.edu.pl

\title{
Protection of Consumers' Rights in Railway in the Slovak Republic
}

\author{
by \\ Matej Horvat, Hana Magurová, Mária Srebalová*
}

\section{CONTENTS}

I. Introduction

II. Railway in the Slovak Republic and customers' satisfaction in railway

III. Public Administration in Railways in the Slovak Republic

IV. Consumers' Rights in Railway in the Slovak Republic

V. Conclusions

\begin{abstract}
The paper focuses on railway services in the Slovak Republic and describes the organization of public administration in this area and its responsibility for protecting consumer rights. It analyses customers' rights stipulated in the Slovak legislation and comes to a conclusion that they drive mainly from the EU law. The paper also presents a customer satisfaction survey regarding rail services in the Slovak Republic and several other EU states and proposes suggestions on how to improve customer satisfaction. The aim is to start a discussion on customers' rights in the Slovak Republic because in the last couple of years the total number of rail customers is on the rise.
\end{abstract}

* JUDr. Matej Horvat, PhD., senior lecturer, Comenius University in Bratislava, Faculty of Law, Department of Administrative and Environmental Law; matej.horvat@flaw.uniba. sk. JUDr. Hana Magurová, PhD., LL.M., senior lecturer, University of Economics, Faculty of Commerce, Department of Business Law; hana.magurova@euba.sk. Doc. JUDr. Mária Srebalová, PhD., associate professor, Comenius University in Bratislava, Faculty of Law, Department of Administrative and Environmental Law; maria.srebalova@flaw.uniba.sk. This paper has been supported via VEGA No. 1/0136/15 "Právna úprava správneho trestania" (Legal Regulation on Administrative Punishment" granted by Ministry of Education, Science, Research and Sports of the Slovak Republic and Slovak Academy of Arts. Article received: 30.12.2016, accepted: 30.05.2017. 


\section{Resumé}

Le papier se concentre sur les services ferroviaires dans la République slovaque et décrit l'organisation de l'administration publique dans ce domaine et sa responsabilité de protéger des droits des consommateurs. Il analyse les droits des clients prévus par la législation slovaque et conclut qu'ils découlent principalement du droit communautaire. Le document présente également une enquête sur la satisfaction des clients concernant les services ferroviaires dans la République Slovaque et plusieurs autres états de l'UE et propose des suggestions sur la manière d'améliorer la satisfaction des clients. Ĺobjectif est d'entamer une discussion sur les droits des clients dans la République Slovaque, parce que le nombre total de clients ferroviaires est en hausse depuis quelques années.

Key words: customer rights in railways; Ministry of Transport; protection of customers' rights in railway, public administration in railway; railway; Regulation (EC) No. 1371/2007; Slovakia; Transport Authority.

JEL: K23

\section{Introduction}

A strong influence of EU legislation is seen when it comes to protection of consumer rights in all markets of transport services ${ }^{1}$. This applies to railways as well. The main source of railway passenger rights is stipulated by Regulation (EC) No 1371/2007 of the European Parliament and of the Council of 23 October 2007 on rail passengers' rights and obligations (hereinafter, Regulation $)^{2}$. But a long path has led to adopting this Regulation.

The first important EU legal act on railways was the First Railway Directive $^{3}$. Its aim was to separate the management of railway operations and infrastructure from the provision of railway transport services (separation of accounts being compulsory and organizational or institutional separation being optional). After that there was Council Directive 95/18/EC of 19 June 1995 on the licensing of railway undertakings ${ }^{4}$ that concerned the criteria applicable to the issue, renewal or amendment of licences by a Member State intended for railway undertakings which are or will be established in the Community;

1 See Article 90-100 TFEU (especially Article 90, 91 and 100).

2 OJ L 315, 3.12.2007, p. 14-41.

3 Council Directive 91/440/EEC of 29 July 1991 on the development of the Community's railways (OJ L 237, 24.8.1991, p. 25-28).

4 OJ L 143, 27.6.1995, p. 70-74. 
a license provided in one Member State has been henceforth generally valid in all other member states. And finally Council Directive 95/19/EC of 19 June 1995 on the allocation of railway infrastructure capacity and the charging of infrastructure fees ${ }^{5}$ that defined the principles and procedures to be applied with regard to the allocation of railway infrastructure capacity and the charging of infrastructure fees for railway undertakings which are or will be established in the Community and the international groupings which they form (Král, 2011).

Since May 1, 2004 all EU law applies to the Slovak Republic as Slovak Republic became one of the EU Member States.

When it comes to the Slovak Republic, besides EU law, we have to name two national statutes for they stipulate a lot of legal regulations concerning railways. They are:

1) Act No. 513/2009 Coll. on tracks as amended and

2) Act No. 514/2009 Coll. on service on tracks as amended.

Railways and service on railways are mainly regulated by these two acts ${ }^{6}$.

\section{Railways in the Slovak Republic and customers' satisfaction}

Pursuant to Act No. 513/2009 Coll. there are three types of tracks in the Slovak Republic:

1) railways,

2) trolley tracks,

3) cableways.

Railways are train tracks, tram tracks and special tracks. Special tracks are for example subways ${ }^{7}$. Tram tracks are used for city transport only and as of today are built only in Bratislava and Košice ${ }^{8}$. Train tracks are widely used to connect cities and regions of the Slovak Republic; they are used for international connection also. There are 3 Paneuropean train corridors (corridors IV, V and VI) in the Slovak Republic.

5 OJ L 143, 27.6.1995, p. 75-78.

${ }^{6}$ Literature mentions much more legislation (Kropaj, 2016).

7 However there are no subway tracks in Slovak Republic. Subway track was started to be built in the capital city of Bratislava in 1989. Subsequent social changes following 1989 have caused termination of this project.

8 The last operator is Leo Express. 
Map 1: A map of railways in the Slovak Republic



Source: http://www.zsr.sk/slovensky/zeleznicna-dopravna-cesta/marketing/tabulky-tratovychpomerov/mapa-siete-zsr.html?pageid=921 (8.12.2016).

According to the 2016 Annual Report of Železnice Slovenskej republiky, a. s., (Slovak railways operator), there are $3626 \mathrm{~km}$ of train tracks operated by the end of 2016 in the Slovak Republic ${ }^{9}$. Rail freight transport is operated mainly by Železničná spoločnost̉ Cargo Slovakia, a. s., and rail passenger transport is provided mainly by Železničná spoločnost̉ Slovensko a. s. (hereinafter, ZSSK). All of these companies are state-owned. Rail personal transport is provided by several private companies also, the most known is RegioJet, a. s. ${ }^{10}$ Hereinafter, ZSSK and RegioJet may be together referred to as service operators.

For purposes of this paper the term "railways" means passenger rail transport. Since railways are gaining in importance, it is much needed to point out all the main rights of its customers and describe how they are being enforced. The rise in rail customers is presented in Chart 1 below.

9 Retrieved from: http://www.zsr.sk/buxus/docs/vyrSpravy/VyrocnaSprava2016.pdf (18.07.2017).

10 This private company has started offering its services since March 14, 2012. At the beginning it was operating a regional track from Bratislava to Komárno. Since December 2014 it has started offering its services for the main train track between Bratislava and Košice. 
Chart 1: Number of rail customers in the Slovak Republic (in millions)

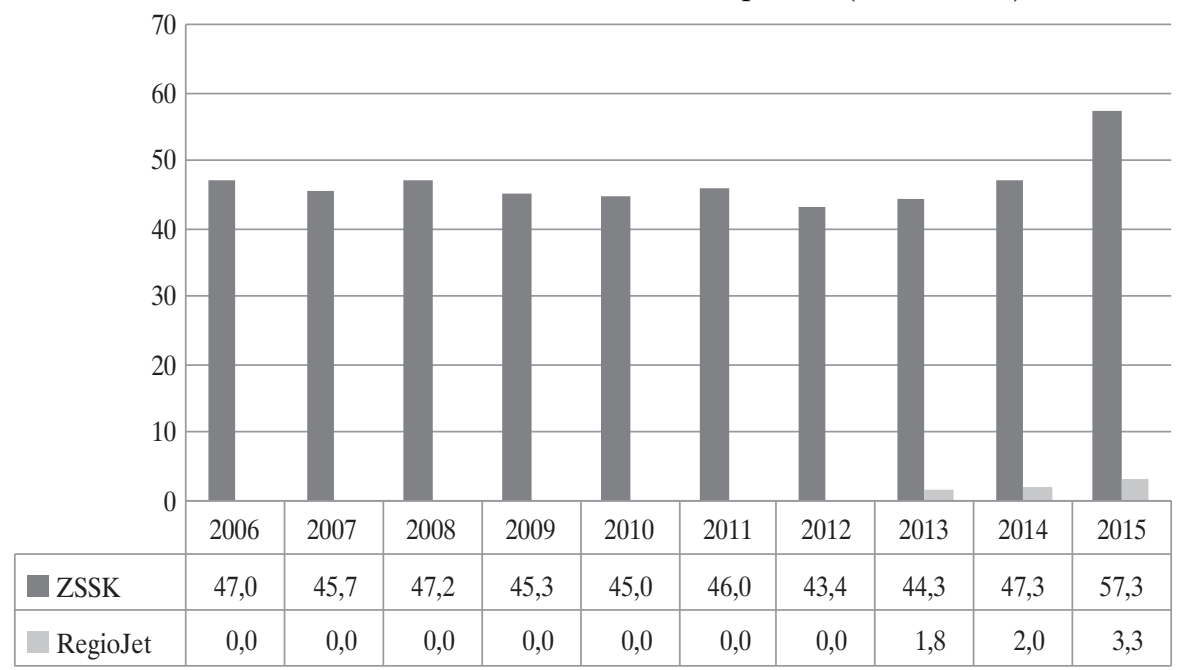

Sources: Annual Report of Železničná spoločnost̉ Slovensko, a.s. for 2015, retrieved from: http://www.slovakrail.sk/fileadmin/Dokumenty2/2016_pdf/VS_2015_EN.PDF (3.12.2016) and Annual Report of RegioJet, a. s., 2015, retrieved from: https:/www.regiojet.sk/dokumenty/ (3.12.2016); own adaptation.

There is a significant rise in total numbers of customers for ZSSK in 2015 (by $21 \%)^{11}$. This was the consequence of the introduction of a was caused because free of charge transport for selected groups of persons (children, students and seniors) by the government as of November 17, 2014'12. If we compare data from 2014 and 2015 there is a huge rise of 11.3 million rail customers (ZSSK and RegioJet combined).

There is no doubt that given those numbers, railways have a great impact on the economy and society (Pekár, 2012), with ZSSK being one of the biggest employers in the Slovak republic. Given the ubiquity of rail service, customer satisfaction can be a major factor influencing their performance.

11 The rise for RegioJet was even $65 \%$. This was caused due to reasons mentioned in the previous reference.

12 Free of charge transport does not apply to IC trains between Bratislava and Košice. It applies to all regional railways. It applies for international railway too but only through territory of the Slovak Republic. Free of charge transport applies also to private provider RegioJet (to minimalize its financial loss this provider got 7 million $€$ subside from the state budget). There are no official data on how this governmental measure has cost the state budget. As of yet, unofficial data states it is approximately 13-15 million $€$ per year. Source: http://www. topky.sk/cl/100535/1547567/Minister-Brecely-prezradil--kolko-stat-stoja-vlaky-pre-studentov-adochodcov--Zadarmo-rozhodne-nie-su (7.12.2016). 
The EU conducts several surveys on how customers are satisfied on a given market. One of the surveys is called The Consumer Market Monitoring Survey (hereinafter, Survey). It tracks the functioning of consumer markets across the EU, Iceland and Norway. It provides data for the Consumer Markets Scoreboard. The Survey is conducted since 2010 (up until 2013 on an annual basis). The Survey allows ranking markets on the basis of the Market Performance Indicator (hereinafter, MPI): a composite index taking into account five key aspects of consumer experience: comparability ${ }^{13}$, trust $^{14}$, expectations ${ }^{15}$, choice ${ }^{16}$, overall detriment ${ }^{17}$. The five components of the index are weighted on the basis of their relative importance as stated by consumers and the maximum total score is 100 . In addition, the Survey also covers complaints $^{18}$ and switching ${ }^{19}$. The resulting number from all key aspects of consumer experience indicates how well a given market performs according to consumers. Last Survey was taken in 2015.

The Survey was produced under the EU Consumer Programme (2014-2020) in the frame of a service contract with the Consumers, Health, Agriculture and Food Executive Agency (CHAFEA) acting under the mandate from the European Commission ${ }^{20}$. The Survey was focused on several service markets ${ }^{21}$. One of them is a market of train services. The results, presented in Chart 2, provide a relevant context for this paper.

13 It assesses how easy or difficult it is for consumers to compare goods or services as they are offered by different suppliers or providers in a market.

14 It measures the extent to which consumers are confident that suppliers, or providers, respect the rules and regulations that protect the consumer.

15 It is a dimension that measures the extent to which the market meets consumers' expectations.

16 It measures the level of competition and the choice of retailers/providers in a given market.

17 It assesses the extent to which consumers who experienced a problem suffered financial loss or other detriment as a result.

18 It measures the propensity to complain to the seller/provider and/or third parties if problems are experienced.

19 It asks whether consumers have changed provider within the market timeframe. Depending on their answer, consumers are then asked about the ease of switching - how easy or difficult they think it was to switch - or about their reason for not switching. Retrieved from: http://ec.europa.eu/consumers/consumer_evidence/consumer_scoreboards/market_monitoring/ index_en.htm (4.12.2016)

${ }^{20}$ Retrieved from: http://ec.europa.eu/consumers/consumer_evidence/consumer_ scoreboards/market_monitoring/docs/mms2015_final_report_part_i_en.pdf (4.12. 2016).

21 A total of 29. For example: holiday accommodation, gas services, postal services, legal and accountancy services, internet provision, mortgages, airline services, mobile telephone services, postal services, etc. 
Chart 2: Average Survey results for Train Service (MPI)

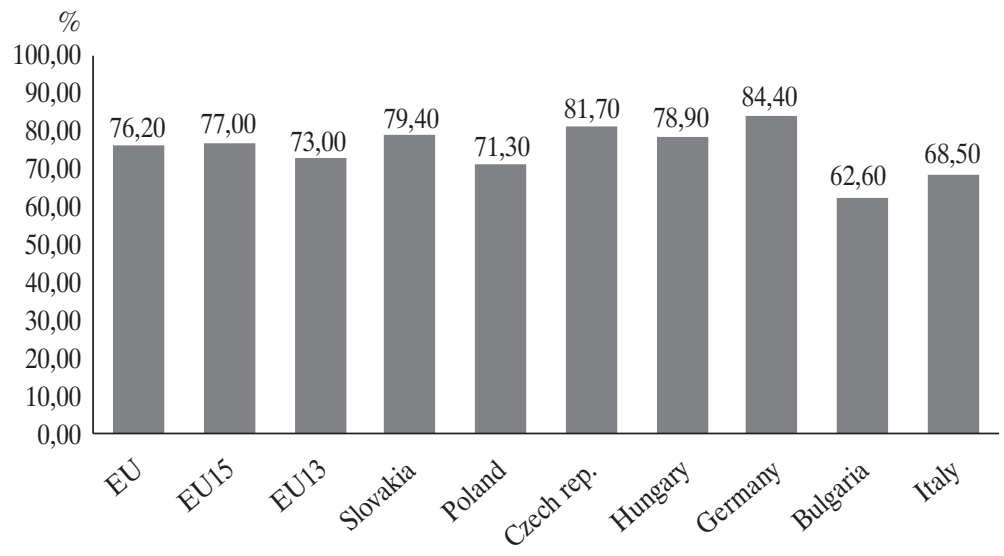

Source: http://ec.europa.eu/consumers/consumer_evidence/consumer_scoreboards/market_ monitoring/docs/mms2015_final_report_part_ii_en.pdf (4.12.2016); own adaptation.

There are almost no differences in the overall scores between EU15 and EU13 and the average score for the whole EU. But train services in EU13 are perceived 3.2 percentage points below the EU average and $4.0 \mathrm{pp}$. below EU15 average. This indicates significantly lower satisfaction with train services in EU13.

The chart also shows satisfaction scores of selected EU countries. The most satisfied customers of train services ${ }^{22}$ are from Germany, while the most dissatisfied are from Bulgaria.

When it comes to the Slovak Republic, customer perception of train services is better than the EU average as well as the average Slovak MPI score for all of the Survey's 29 service markets. Also the perception of train services in Slovakia has improved by 6.1 percentage points compared to the 2013 results. However, it seems that customer satisfaction can still improve when it comes to Slovak rail services.

\section{Public administration in railways in the Slovak Republic}

Public administration in the Slovak Republic is divided by legal theory into state administration (conducted primarily by various state bodies)), self-

22 The top three ranked countries for this market are Lithuania (89.6), Luxembourg (85.9) and Austria (85.2), while Bulgaria (62.6), Croatia (63.8) and Romania (68.2) are at the other end of the scale. 
government (local and professional) and so-called other public administration (Škrobák, 2012).

Organization of public administration in railways in Slovakia consists of:

1) Ministry of Transport, Construction and Regional Development of the Slovak Republic (hereinafter, Ministry) as a central state administration body (it has territorial competence over the whole area of Slovakia),

2) Transport Authority as other state administration body (it has territorial competence over the whole area of the Slovak Republic; despite this fact Transport Authority is not a central state administration body. It is subordinated to the Ministry).

Several competences are also given to:

1) units of local self-government (they have territorial competence over eight regions of the Slovak Republic); some of their competences are delegated on higher territorial unit by law therefore they conduct delegated state administration ${ }^{23}$ which is financially covered by the state and the state also bears responsibility for the exercise of these competences; and some of the competences are self-governmental competences ${ }^{24}$ which are financially covered by the territorial units themselves and they also bear responsibility for the exercise of these competences,

2) municipalities as a units of territorial self-government (they have a territorial competence over municipal areas of the Slovak Republic; there are approximately 3000 municipalities in the Slovak Republic).

The Ministry manages and monitors the state transport policy; determines priorities in the state transport policy; acts as the investigating body in cases of accidents on railway tracks; and grants exceptions from the Regulation;

The Transport Authority licenses companies for providing railway transport; acts as ssafety and ecurity body for railway transport; and imposes sanctions for breaking obligations.

\section{Consumers' rights in railway in the Slovak Republic}

The basic scope of consumer rights is defined by the Regulation. These rights are perceived as a minimum standard. It means that national legislation

23 All the competences stipulated by the Act No. 513/2009 Coll. For example higher territorial units are investigating bodies in case of accidents on city tracks; Special Building Authority for city tracks; etc.

24 All the competences stipulated by the Act No. 514/2009 Coll. For example higher territorial units are: contractors for regional railway service; licencing bodies and security bodies for city transport; conducting state control over city transport; etc. 
can expand them and guarantee broader customers' rights. However, statutes of the Slovak Republic do not stipulate any extended scope of customers' rights. Apart from the legislation itself, customers' rights could be expanded also by internal regulations of the operators.

However in the area of public law, only rights guaranteed by the Regulation are binding and therefore enforced by public law. This is because of the direct effect of EU regulations. All EU regulations become immediately enforceable as law in all Member States simultaneously. The rights that are stipulated broader in internal regulations of operators are protected in the area of private law. They subject to civil proceedings as a private law dispute 25 .

In general the consumer has a right to get information before and during the journey; to ensure personal safety at stations as well as on board of trains; reimbursement and re-routing; compensation for total or partial loss of registered luggage; other compensations (such as meals and refreshments, hotel or other accommodation) (Magurová, 2016).

Pursuant to the Regulation, there are several exemptions to the rights guaranteed by it. National administrative body could grant exemptions from all of the Regulation's articles (and rights protected by them) except those enumerated in Art. 2(3) of the Regulation; this being:

1) Art. 9 (availability of tickets through tickets and reservations),

2) Art. 11 (liability for passengers and luggage),

3) Art. 12 (insurance),

4) Art. 19 (right to transport),

5) Art. 20(1) (information on the accessibility of rail services and on the access conditions of rolling stock for disabled persons and persons with reduced mobility),

6) Art. 26 (personal security of passangers).

All the above mentioned articles shall apply to all rail passenger services throughout the EU.

In the Slovak Republic, the Ministry is the national administrative body that decides upon exemptions from the Regulation. The Ministry is obliged to inform the Commission of all the exemptions that were granted ${ }^{26}$. As a measure of control, the Commission takes appropriate actions if such an exemption is deemed not to be in accordance with the provision on exemptions in the Regulation.

There are few differences when it comes to the exemptions. The Regulation differs between domestic rail passenger services and urban, suburban and regional rail passenger services. Exemptions on the former can be granted

25 Conditions are laid by Act No. 160/2015 Coll. Code on Civil Dispute Proceedings.

26 A full text of this information (in Slovak language) can be retrieved from: http://www. telecom.gov.sk/index/open_file. php?file=doprava/zeleznica/oznamenie_vynimky.pdf (8.12.2016). 
based on a transparent and non-discriminatory basis and for a period of maximum five years. However this exemption may be renewed twice for a maximum period of five years on each occasion, i.e. for the total period of 15 years. For the latter there is no basis upon which this exception should be granted and also it can be granted for unlimited time.

Slovak operators were granted several exemptions. Their list for domestic rail passenger services is seen in Table 1 . These exemptions were granted for the full period of five years.

Exemptions to urban, suburban and regional rail passenger services are much broader because they were granted towards all articles of the Regulations except those listed in Article 2(3) of the Regulation.

Table 1: Exemptions from the Regulation - Domestic Rail Passenger Services

\begin{tabular}{|c|c|c|}
\hline Article & ZSSK & RegioJet \\
\hline Article 13 & $\checkmark$ & $\checkmark$ \\
\hline Article 15 & $x$ & $\checkmark$ \\
\hline Article 16 & $\checkmark$ & $\checkmark$ \\
\hline Article 17 & $\checkmark$ & $\checkmark$ \\
\hline Article 18 & $\checkmark$ & $\checkmark$ \\
\hline Article 21 & $\checkmark$ & $\checkmark$ \\
\hline Article 22 & $\checkmark$ & $\checkmark$ \\
\hline Article 23 & $x$ & $\checkmark$ \\
\hline Article 26 & $x$ & $\checkmark$ \\
\hline Article 28 & $x$ & $\checkmark$ \\
\hline
\end{tabular}

Sources: http://www.slovakrail.sk/sk/o-spolocnosti/prava-cestujucich/prava-a-povinnosti-cest ujucich.html and https://www.regiojet.sk/opencms/export/sites/regiojet.sk/dokumenty/prepr avny-poriadok/PP_od_17.7.pdf (8.12.2016); own adaptation.

The biggest means for achieving a great competitive advantage is through reimbursement and re-routing when the delay in the arrival at the final destination under the transport contract is more than 60 minutes (Magurová, 2016). The Regulation sets out rules for compensation of the ticket price as follows. The minimum compensations for delays is

1) $25 \%$ of the ticket price for a delay of 60 to 119 minutes,

2) $50 \%$ of the ticket price for a delay of 120 minutes or more ${ }^{27}$.

27 The passenger does not have any right to compensation if he/she is informed of a delay before he/she buys a ticket, or if a delay due to continuation on a different service or re-routing remains below 60 minutes. 
In Chart 3 you can see data on delays of RegioJet ${ }^{28}$. The number means how big a share of all train services were delayed. Unfortunately, ZSSK did not publish any data that would provide us the same chart as seen in the Chart 3. ZSSK published only information on how many international train services were delayed. Therefore the percentage shares in Chart 4 means how many delayed train services were delayed by their respective time.

Chart 3: Delays RegioJet

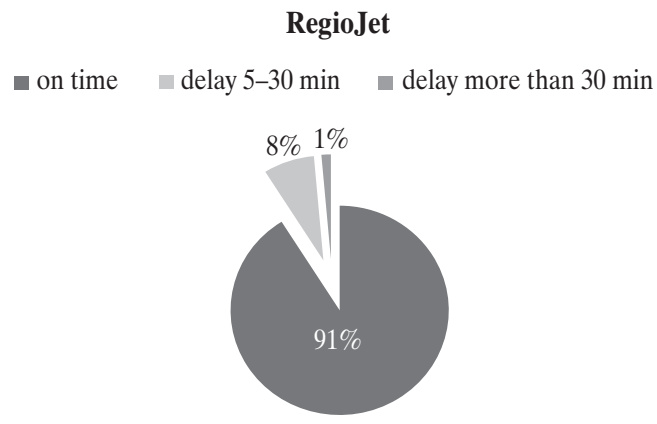

Source: https://www.regiojet.sk/opencms/export/sites/regiojet.sk/dokumenty/pdf-sk/sprava-o-kva lite-2015.pdf (8.12.2016); own adaptation.

Chart 4: Delays ZSSK
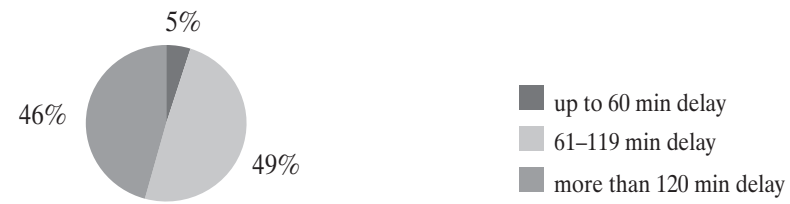

Source: http://www.slovakrail.sk/sk/o-spolocnosti/prava-cestujucich.html; (q. December 9, 2016); own adaptation.

Lastly, in Chart 5 you can see how many complaints on delays were considered legitimate and therefore were compensated by operators since 2012 .

28 There are only data on domestic railways when it comes to RegioJet. When it comes to ZSSK there are no official data on how many train services are provided per day. Source: http:// www.webnoviny.sk/ekonomik a/clanok/1080716-pozor-na-zmeny-zeleznice-upravili-bezplatnecestovanie/ there are 1455 train services per day which means 531075 train services per year. Nevertheless a data for ZSSK could not be used because ZSSK published only data on how many train services in international railway were delayed. 
Chart 5: Legitimate complaints on delays

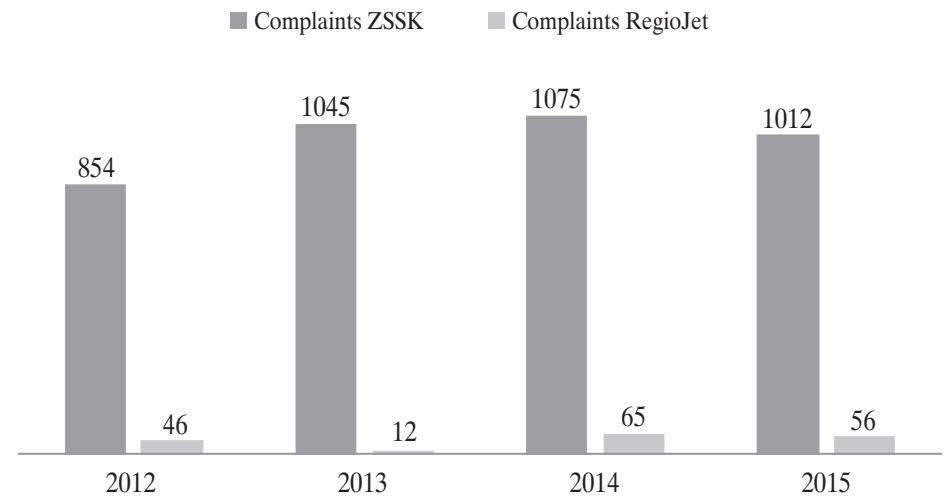

Source: https://www.regiojet.sk/dokumenty/ and http://www.slovakrail.sk/sk/o-spolocnosti/pravacestujucich.html (9.12.2016); own adaptation.

It was already mentioned that in domestic railway services, the Ministry has informed the Commission on exemptions from all the articles of the Regulation (naturally except those enumerated in Article 2(3)). RegioJet does not apply the exemption from Article 17. Pursuant to this Article, a minimum delay for granting any compensation is 60 minutes.

However, according to the Internal Passenger Regulation of RegioJet if a railway service is delayed more than five minutes upon the boarding station, the customer has a right to either cancel the trip or board the train. If he/she cancels, he/she is entitled to get the full ticket price back. If he/she chooses to continue on his/hers journey, then he/she is entitled to claim:

1) $10 \%$ of the ticket price if the train is $30-59$ min. delayed,

2) $50 \%$ of the ticket price if the train is $60-119$ min. delayed,

3) $100 \%$ of the ticket price if the train is delayed over $120 \mathrm{~min}$.

There is no similar provision in the Internal Passenger Regulations of the state-owned company ZSSK.

Pursuant to Article 30 of the Regulation, each Member State shall designate a body or bodies responsible for the enforcement of this Regulation and each body shall take the measures necessary to ensure that the rights of passengers are respected. As a means of ensuring that the customers' rights are protected, Act No. 514/2009 Coll. stipulates a special administrative offence. Pursuant to Article 43(1)(c) of the Act, a licensing body imposes a financial fine up to $1,000 €$ on an operator that violates customers' rights granted by the Regulation. Such proceedings can begin within six months since the licencing body has known of such violation but maximum up to three years since the actual violation of the right. 
When it comes to railways (train service), this licencing body is Transport Authority.

A party to the proceedings can file an appeal against decision of Transport Authority. The appellate body is the Ministry. Administrative proceedings are conducted under Act No. 71/1967 Coll. Code on Administrative Proceedings.

The party to the proceedings can then file an administrative action against final decision of the Ministry. The conditions for filing the action are laid by Act No. 162/2015 Coll. Code on Administrative Justice Proceedings.

\section{Conclusions}

The rise of total numbers of customers means that there will be more discussions about their rights and how to protect them. A leading role in protecting customers' rights plays the EU regulation. As of today, EU adopted four railways packages ${ }^{29}$, with the final goal of creating a single European rail area.

When it comes to customers' rights, the most important legal act that stipulates them, is the Regulation. It adopts the minimum standard of rights that are granted to rail customers. National legislation can grant even broader scope of the rights. However, this is not the case of the Slovak Republic. Slovak legislation is fully following the rights stipulated in the Regulation.

The most known right of the customer is the compensation for the ticket price when the train is delayed for at least 60 minutes. This right can be even used as means of competition for customer. Pursuant to the Regulation, the compensation of at least $25 \%$ of the ticket price is granted for a delay of 60 to 119 minutes and at least $50 \%$ of the ticket price is granted for a delay of 120 minutes or more. A disadvantage of the Regulation is that a Member State can claim exemptions from its articles. These exemptions could be granted either for a period of maximum 15 years, or even for unlimited time period. If a Member State chooses to claim the exemption, it has to inform EU about this step. EU could prevent such exemption if it is deemed not to be in accordance with the provision on exemptions in the Regulation.

29 The last (so far) fourth railway package was adopted in December 2016. The fourth railway package aims to remove the remaining barriers to the creation of a single European rail area. The proposed legislation would reform the EU's rail sector by encouraging competition and innovation in domestic passenger markets. It would also implement structural and technical reforms (http://www.consilium.europa.eu/en/policies/4th-railway-package/ (22.12.2016). See more on; http://www.europarl.europa.eu/news/en/news-room/20160427BKG24994/the-4thrailway-package; http://ec.europa.eu/transport/modes/rail/packages/2013_en. 
Administrative body that is responsible for claiming the exemptions in the name of the Slovak Republic is the Ministry. The Slovak Republic claimed exemptions from all the articles of the Regulation when it comes to urban, suburban and regional rail passenger services. Several exemptions are granted from domestic rail passenger services too. They are shown in Table 1. However, the Regulation also stipulates that rights enumerated in Art. 2(3) ${ }^{30}$ do not subject to any exemptions and therefore no Member State can claim exemptions from rights enumerated therein.

When it comes to reaching EU transport goals, it is needed to know customers' opinions and level of satisfaction. Customers' satisfaction with railway is being under the scrutiny of EU. EU regularly conducts surveys on the matter. The result for train services in the Slovak Republic is average, which means that there is still much to do if we want to achieve (for example) a level of satisfaction as is in Germany. In order to do so, operators should always try to take great care of their customers by (e.g.) providing high quality services; avoiding increase of delays; informing customers about every aspect of their journey including information on any harm (for example resulting from delay); etc. One way of achieving high level of satisfaction of customers is to grant them more rights than only those that operators are obliged to provide.

\section{Literature}

Král, R. (2011). Dopravní politika. In: L. Tichý et al. Evropské právo (pp. 693-694). Praha: C.H. Beck.

Kropaj, M. (2016). Medzinárodné a európske pramene v cestovnom ruchu. In: H. Magurová et al. Základy práva v cestovnom ruchu (pp. 25-30). Bratislava: Wolters Kluwer.

Magurová, H. (2016) Práva cestujúcich v leteckej, železničnej, autobusovej a lodnej doprave (pp. 149-150). In: H. Magurová et al. Základy práva v cestovnom ruchu. Bratislava: Wolters Kluwer.

Pekár, B. (2012). Správa dopravy. In: M. Vrabko et al. Správne právo hmotné. Osobitná čast'. Bratislava: Univerzita Komenského v Bratislave, Právnická Fakulta.

Škrobák, J. (2012). Verejná správa v organizačnom ponímaní. In: M. Vrabko et al. Správne právo hmotné. Všeobecná čast' (pp. 11-16). Bratislava: C.H. Beck.

30 They are as follows: availability of tickets, through tickets and reservations; liability for passengers and luggage; insurance; right to transport; information to disabled persons and persons with reduced mobility; personal security of passengers. 